\title{
Bioterrorism - threat to regional security and global
}

\section{Bioterroryzm - zagrożeniem dla bezpieczeństwa regionalnego i światowego}

\author{
Piotr Daniszewski \\ Faculty of Biology, University of Szczecin, 13 Waska Street, 71-415 Szczecin, Poland \\ E-mail address: daniszewski73@gmail.com
}

\begin{abstract}
„, Granica między terroryzmem, a wojna wcią̇ będzie się zacierać. $W$ konsekwencji zapobieganie i przeciwdziałanie terroryzmowi stanie się o wiele ważniejsze $w$ dziedzinie bezpieczeństwa i polityki obronnej. Sity zbrojne będa musiaty przystosować się do nowych okoliczności. Zwiększy się więc rola, jakq w zwalczaniu terroryzmu odegraja dowódcy operacji specjalnych i sily, które im podlegaja. Priorytetem stanie się tworzenie specjalistycznych jednostek i prowadzenie badan nad neutralizowaniem broni chemicznej i biologicznej."
\end{abstract}

Francois Heisbourg [32]

\begin{abstract}
Bioterrorism is a multi-faceted phenomenon and dynamic, occurring in various forms. It is difficult now to define a uniform definition of terrorism that is changing under the influence of the development of civilization, and especially the rapid scientific progress. The terrorists perfectly use the latest achievements of biological sciences in their terrorist attacks. The purpose of this article is to bring the phenomenon of bioterrorism.
\end{abstract}

Keywords: terrorism; bioterrorism; the threat; security; terrorist attack

\section{STRESZCZENIE}

Bioterroryzm to zjawisko wielopłaszczyznowe i dynamiczne, występujące $\mathrm{w}$ różnych postaciach. Trudno jest obecnie zdefiniowanie jednolitej definicji terroryzmu, który zmienia się pod wpływem rozwoju cywilizacyjnego, a zwłaszcza szybkiego postępu naukowego. Terroryści perfekcyjnie wykorzystują najnowsze zdobycze nauk biologicznych w swoich atakach terrorystycznych. Celem artykułu jest przybliżenie zjawiska bioterroryzmu.

Stowa kluczowe: terroryzm, bioterroryzm, zagrożenie, bezpieczeństwo, atak terrorystyczny. 


\section{WPROWADZENIE}

Termin terror wywodzi się od słowa tras, które oznacza drżeć [1-8,10,11]. Jednak do wyjaśniania tego zjawiska o wiele trafniejsze jest stosowanie łacińskiego słowa terror oznaczającego przestrach, postrach, przerażenie, strach, trwogę [1-8,10,11].

Działania terrorystyczne były od wieków stosowane jako skuteczne narzędzie walki przeciwko silniejszemu przeciwnikowi [20-25,29-31]. Za jedną $\mathrm{z}$ najwcześniejszych organizacji terrorystycznych (lata 66-70 n.e.) uważani są tzw. sicarii (nożownicy), będący sektą religijną w Palestynie [1-5,27]. Walczyli oni przeciwko panowaniu Rzymian, atakując osoby decyzyjne i niszcząc obiekty użyteczności publicznej [6,8,26-32].

Terroryzm stał się w XX i na początku XXI wieku jednym z najgroźniejszych zjawisk zagrażających bezpieczeństwu na świecie [30,31]. Choć zjawisko to jest prawie tak samo stare, jak ludzkość, jednak w odróżnieniu od przeszłości współcześnie działający terroryści stosują przemoc na szersza skalę [7-14,25-29]. Terroryści doskonalą i brutalizują metody swojego działania, a poprzez umiędzynarodowienie działalności zagrażają bezpieczeństwu $\mathrm{w}$ skali narodowej, regionalnej, a nawet globalnej [21-24].

Po 11 września 2001 roku ludzkość uświadomiła sobie skalę zagrożeń, jakie niesie dla niej terroryzm. Dotychczasowe zamachy niepokoiły opinię publiczną, niekiedy były szokiem dla pewnych społeczeństw, ale nigdy przedtem zjawisko to nie wywoływało tak szerokiego „rezonansu” społecznego [19-24,27-31]. W krajach, które wcześniej doświadczyły aktów terroru, stopień uświadomienia społeczeństw i rządzących był większy [7,19,24-31]. W tych krajach podejmowano również działania, których celem było zapobieganie zamachom i sprawna likwidacja ich skutków [1-8,26-30]. Wiadomo było, że terroryści mogą używać broni masowego rażenia, w tym broni biologicznej [10-15,19-25]. Można było tak sądzić na podstawie znajomości walorów tego typu broni (łatwa i tania w produkcji, łatwa do magazynowania $\mathrm{i}$ przenoszenia, niewidzialna $\mathrm{w}$ czasie ataku, trudna do wykrycia $\mathrm{i}$ identyfikacji), a także na podstawie dotychczasowych doświadczeń [11-14,19-24,27].

Według dostępnych informacji wiadomo, że kilkanaście państw rozwija stale technologie związane z produkcją broni biologicznej, a około 20 państw taką broń posiada i dysponuje środkami jej przenoszenia [19-24,27]. Wśród tych państw znajdują się również takie, które podpisały, a nawet ratyfikowały Konwencję z 1972 roku o zakazie produkcji, magazynowania broni biologicznej oraz o jej zniszczeniu, a także są sygnatariuszami Protokołu Genewskiego z 1925 roku [13-17,19-24] Na liście tej znajdują się również państwa popierające terroryzm i wspierające konkretne organizacje terrorystyczne [17-24,30-32].

\section{DEFINICJA BIOTERRORYZMU}

Istnieje około 100 definicji charakteryzujących zjawisko bioterroryzmu. Według FBI „terroryzm to bezprawne (nielegalne) użycie siły przeciwko osobom lub własności zamiarem wymuszenia jakiegoś działania lub zastraszenia rządu, ludności cywilnej lub jakiejkolwiek jej części dla osiągnięcia celów politycznych lub społecznych" [1-3,17-20,24]. Najbardziej znaczącymi zagrożeniami stają się obecnie przede wszystkim te, które dotyczą bezpieczeństwa zwykłych ludzi oraz zagrażają stabilności demokratycznych systemów państwowych i rozwojowi ekonomicznemu [19-24,27]. Terroryzm przy użyciu patogenów to bioterroryzm. Bioterroryzm to zamierzone użycie albo groźba użycia w celu wywołania choroby, zabicia ludzi, zwierząt lub zniszczenia roślin - wirusów, bakterii, grzybów, toksyn produkowanych przez żywe organizmy [9-11,14-19]. 


\section{CEL BIOTERRORYZMU}

Celem bioterroryzmu jest skuteczne wywołanie lęku i paniki wśród ludności a także ekip ratunkowych oraz chaos w wielu dziedzinach życia a także straty ekonomiczne [7-12,1724]. Należy liczyć się z tym, że atak przy użyciu broni biologicznej oprócz strat wywołanych bezpośrednim działaniem wywołałby ogromną panikę, psychozę społeczną i być może nawet zachowania agresywne skierowane przeciwko sprawującym władzę [1-8,10,11,19-24,27]. Według szczegółowych analiz przeprowadzonych przez ekspertów z Centrum Kontroli Chorób w Atlancie ogólne koszty związane z zakażeniem 100 tysięcy ludzi laseczką wąglika (postać płucna) to 26,2 mld. dolarów, w przypadku tularemii koszt wynosi 5,5 mld. dolarów, a w przypadku brucelozy „tylko” 579 mln. dolarów [10,11].

Atak bronią biologiczną może być skierowany pośrednio przeciwko ludziom poprzez zakażenie zwierząt i upraw rolnych [1-2,10,11]. Wymienia się tu drobnoustroje wywołujące schorzenia takie, jak: wąglik, bruceloza, pryszczyca, zapalenie mózgu i rdzenia koni, pomór świń, rzekomy pomór drobiu, księgosusz [1-2,10,11]. Wśród drobnoustrojów branych szczególnie pod uwagę jako narzędzie agroterroryzmu należy wyróżnić wirusa pryszczycy [1$2,10,11,23]$. Istnieje również możliwość skutecznego niszczenia upraw roślinnych oraz zapasów żywności przy użyciu różnych patogenów [1-8,10,11].

\section{PATOGENY, KTÓRE MOGĄ BYĆ UŻYTE W ATAKU BIOTERRORYSTYCZNYM}

Patogeny, które mogą być użyte w ataku bioterrorystycznym są to drobnoustroje, które mają zdolność zakażenia celu, jakim jest eukariotyczny gospodarz oraz wzrastania w nim; prowadzi to do powstania chorób klinicznie rozpoznawalnych, zabijających gospodarza lub powodujących jego niezdolność lub ograniczenie zdolności pełnienia normalnych funkcji życiowych [10,11,19-24,27]. Definicja ta została sformułowana bardzo ogólnie z uwagi na konieczność dostosowania jej do różnych przypadków potencjalnego ataku bioterrorystycznego skierowanego bezpośrednio przeciwko ludziom lub też przeciwko zwierzętom i roślinom mającym znaczenie gospodarcze [10,11,19-24,27].

Patogenne drobnoustroje, które mogą być użyte jako środki ataku biologicznego, zwane biologicznymi czynnikami masowego rażenia mogą być użyte dla realizacji celów:

- militarnych (wojny biologicznej),

- terrorystycznych oraz

- kryminalnych [1-8,10,11,19-24].

Wydaje się jednakże, że wszystkie te trzy kategorie można określić terminem działania kryminalnego, ze względu na to, że większość państw na świecie podpisała Konwencję o Zakazie Broni Biologicznej i Toksynowej [19-24,31-32].

Niebezpieczne czynniki biologiczne brane pod uwagę jako środki ataku biologicznego podzielone zostały na trzy kategorie: A, B, C [10,11,21].

Grupa A: najgroźniejsze czynniki patogenne, charakteryzujące się wysoką zachorowalnością, śmiertelnością oraz szybkim rozprzestrzenianiem, takie jak: wirus ospy prawdziwej (Variola virus), wąglik (Bacillus anthracis), dżuma (Yersinia pestis), tularemia (Francisella tularensis), botulizm (toksyna Clostridium botulinum), wirusy gorączki krwotocznej - filowirusy (np. Ebola, Marburg) oraz arenawirusy (np. Lassa, Machupo) $[10,11,21]$. 
Grupa B: czynniki powodujące umiarkowaną zachorowalność, śmiertelność i tempo rozprzestrzeniania. Zalicza się do nich niektóre czynniki wywołujące choroby zwierząt (gorączka Q - Coxiella burnetii, bruceloza - Brucella, nosacizna - Burkholderia pseudomallei, papuzica - Chlamydia psitacci), choroby wywołane przez patogeny żywnościowe (salmonellozy - Salmonella, czerwonka - Shigella dysenteriae, biegunki krwotoczne - E. coli, cholera - Vibrio cholerae, toksyna Epsilon - Clostridium perfringens), enterotoksyna gronkowcowa B - Staphylococcus aureus, wirusy zapalenia mózgu (końskiego, wenezuelskiego, wschodnio i zachodnioamerykańskiego zapalenia mózgu) oraz toksyna rycynowa (Ricinus communis) [10,11,21].

Grupa C: patogeny, które w przyszłości mogą być obiektem badań inżynierii genetycznej $\mathrm{w}$ kierunku łatwej produkcji i szybkiego rozprzestrzeniania, przy dużej zachorowalności i śmiertelności ( np. wirus Nipah i hantawirus) [10,11,21].

Grupa D: czasem dodatkowo wymienia się tę grupę, na którą składają się patogeny, które prawdopodobnie nigdy nie zostaną wykorzystane jako broń biologiczna (np. wirus grypy - łatwy do rozpoznania przez epidemiczne występowanie, wirus HIV - przez długi okres utajenia) $[10,11,21]$.

Table 1. Potential pathogens that could be used in an attack bioterrorism [10, 11, 21].

Tabela 1. Potencjalne patogeny, które mogą być wykorzystane w ataku bioterrorystycznym $[10,11,21]$.

\begin{tabular}{|c|c|c|}
\hline Katograria & Patogeny & Wywoływane choroby \\
\hline & Wirus ospy & Ospa prawdziwa [NATO] \\
\hline $\begin{array}{l}\mathrm{A} \\
\mathrm{A} \\
\mathrm{A} \\
\mathrm{C} \\
\mathrm{C}\end{array}$ & Wirusy gorączek krwotocznych & 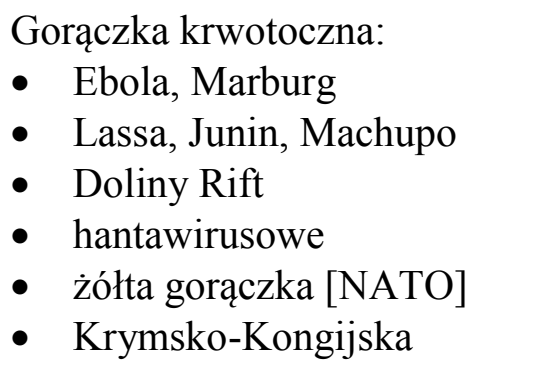 \\
\hline $\begin{array}{l}\text { B } \\
\text { B } \\
\text { B }\end{array}$ & Wirusy zapalenia mózgu & $\begin{array}{l}\text { Zapalenie mózgu } \\
\text { - } \quad \text { wschodnie końskie } \\
\text { - } \text { zachodnie końskie } \\
\text { - } \quad \text { wenezuelskie [NATO] }\end{array}$ \\
\hline
\end{tabular}


Table 2. Potential pathogens - priority selection by NATO [10,21].

Tabela 2. Potencjalne patogeny - priorytetowa selekcja wg NATO [10,21].

\begin{tabular}{|c|l|l|}
\hline Kategoria CDC & \multicolumn{1}{|c|}{ Patogeny } & \multicolumn{1}{|c|}{ Wywolywane choroby } \\
\hline A & Bacillus anthracis & Wąglik [NATO] \\
A & Yersinia pestis & Dżuma [NATO] \\
A & Francisella tularensis & Tularemia [NATO] \\
B & Brucella melitensis & Gorączka maltańska [NATO] \\
B & Burkholderia mallei & Choroba Banga \\
B & Brucella abortus & Cholera [NATO] \\
B & Vibrio cholerae & Salmoneloza \\
B & Salmonella sp. & Czerwonka \\
B & Shigella & Enterokrwotoczne zapalenie jelita \\
B & Escherichia coli, O157 & Gruźlica \\
C & Mycobacterium tuberculosis & (wielooporny) \\
\end{tabular}

\section{WNIOSKI}

1. Broń biologiczna jest jednym z najważniejszych zagrożeń nie tylko dla sił zbrojnych, lecz również dla ludności cywilnej we współczesnym świecie.

2. Ataki terrorystyczne $\mathrm{z}$ użyciem broni biologicznej mogą nastąpić poprzez rozpylenie aerozolu, skażenie żywności i ujęć wody oraz metodami niekonwencjonalnymi takimi jak - np.: w przesyłkach, poprzez skażenie przedmiotów użytku codziennego, środków komunikacyjnych, itp.).

3. Wiedza na temat bioterroryzmu wśród społeczeństwa nie tylko w Polsce, ale również na świecie jest niewielka. Bardzo ważnym elementem zapobiegania i skutecznego przeciwdziałania skutkom biologicznych środków rażenia jest posiadanie sprawnego i zintegrowanego systemu nadzoru epidemiologicznego oraz sieci wyspecjalizowanych akredytowanych laboratoriów mikrobiologicznych zdolnych do szybkiej diagnostyki.

4. Bardzo ważną kwestią jest odpowiednie wyszkolenie i wyposażenie personelu służb ratowniczych i służby zdrowia działających według opracowanych procedur przez służby odpowiedzialne za bezpieczeństwo. 


\section{References}

[1] Aleksandrowicz T. R., Nowy terroryzm, [w:] Współczesne zagrożenia terroryzmem oraz metody działań antyterrorystycznych, red. J. Szafrański, Szczytno 2007.

[2] Altermatt U., Sarajewo przestrzega. Etnonacjonalizm w Europie, Znak, Kraków 1998 r.

[3] Archick K., Gallis P., Europe and Counterterrorism, Nova Science Publishers, New York 2003.

[4] Barcz J., Prawo Unii Europ - zagadnienia systemowe, Prawo i Praktyka Gospodarcza, Warszawa 2002 r.

[5] Barcz J., Traktat z Nicei - zagadnienia prawne i instytucjonalne, Prawo i Praktyka Gospodarcza, Warszawa 2003 r.

[6] Beck U., Władza i przeciwwładza w epoce globalnej. Nowa ekonomia polityki światowej, Wyd. Naukowe Scholar, Warszawa 2005.

[7] Białek Tomasz, Terroryzm manipulacja strachem, Studio EMKA, Warszawa 2005.

[8] Bieleń S., Prawo w stosunkach międzynarodowych. Wybór dokumentów, Warszawa 1988

[9] Bożek M., Troszyński M. (red.), Europa - kontynent ryzyka? Społeczne, polityczne i normatywne uwarunkowania bezpieczeństwa w Europie, Wyd. AON, Warszawa 2007.

[10] Chomiczewski K., Kocik J., Szkoda M. T., Bioterroryzm. Zasady postepowania lekarskiego, Warszawa, Wydawnictwo Lekarskie PZWL, 2002.

[11] Chomiczewski K., Przegląd Epidemiologiczny 57 (2003) 349-53.

[12] Flemming M., Terroryzm polityczny w międzynarodowym prawodawstwie, „Wojskowy Przegląd Prawniczy nr 1, 1996.

[13] Jenkins B. M., International Terrorism. A New Mode of Conflict. California Seminar on Arms Control and Foreign Policy, Los Angeles 1975,

[14] Kiełtyka A., Amerykańska ustawa antyterrorystyczna z 2001r. (The USA Patriot Act of 2001) Prokurator, nr 2-3 (22-23) 2005.

[15] Koziej S., Między piektem a rajem: szare bezpieczeństwo na progu XXI wieku, Wyd. Adam Marszałek, Torun 2006.

[16] Kumaniecki K., Stownik łacińsko-polski, Państwowe Wydawnictwo Naukowe, Warszawa 1982.

[17] Kunikowski J., Turek A. (red.), Bezpieczeństwo i dyplomacja. Słownik terminów, Wyd. Pedagogium, Warszawa 2008.

[18] Laqueur W., Reflections on Terrorism, - Foreign Affairs No 1, Vol. 65, 1986.

[19] Liedel K., Piasecka P., Wspótpraca międzynarodowa w zwalczaniu terroryzmu, Oficyna Wydawnicza Adam, Warszawa 2004,

[20] Machowski A., Zagrożenia bioterroryzmem. Dydaktyczno - prewencyjne aspekty zarządzania bezpieczeństwem społecznym, Mysłowice 2008. 
[21] Madej M., Użycie sity przez podmioty pozapaństwowe jako „,nowy problem studiów strategicznych, [w:] Stosunki międzynarodowe w XXI wieku. Księga jubileuszowa z okazji 30-lecia Instytutu Stosunków Międzynarodowych Uniwersytetu Warszawskiego, red. E. Haliżak, R. Kuźmiar, G. Michałowska, S. Parzymies, J. Simonides, R. Zięba, Warszawa 2006.

[22] Madej M., Zagrożenia asymetryczne bezpieczeństwa państw obszaru transatlantyckiego, Polski Instytut Spraw Międzynarodowych, Warszawa 2007,

[23] Malec M., Percepcja bezpieczeństwa: definicje, wymiary, paradygmaty, Wyd. MON, Warszawa 2006.

[24] Moss R., Urban Guerilla Warfare, Adelphi Paper, No 79, London 1971,

[25] Muszyński J. (red.), Terroryzm polityczny, Warszawa 1981,

[26] Oakley R., International Terrorism, „Foreign Affairs, America and the World No 3, Vol. 65, 1987,

[27] Pikulski S., Prawne środki zwalczania terroryzmu, Olsztyn 2000

[28] Szlachter D., Walka z terroryzmem w Unii Europejskiej. Nowy impuls, Torun 2006

[29] Zieliński K., Brocki M., Janiak M., Wiśniewski A., Patologia obrażeń i schorzeń wywołanych współczesna bronia $w$ działaniach wojennych i terrorystycznych, Wydawnictwo MON, Warszawa, 2010.

[30] Żuber M.(red.), Katastrofy naturalne i cywilizacyjne. Zagrożenia cywilizacyjne początku XXI wieku, WSOWL, Wrocław 2007.

[31] Protokół Kartageński o Bezpieczeństwie Biologicznym do Konwencji o Różnorodności Biologicznej. Dz..U. z 2004 r., Nr 216, poz. 2201.

[32] Heisbourg F., Wojny, Prognozy XXI wieku, Warszawa: Prószyński i S-ka, 1998, s. 55. 